\title{
Strategi komunikasi terapeutik dalam pengobatan korban kekerasan seksual
}

\author{
Encep Dulwahab ${ }^{1}$, Yeni Huriyani ${ }^{2}$, Asep Saeful Muhtadi ${ }^{3}$ \\ 1,2,3UIN Sunan Gunung Djati, Bandung, Indonesia
}

\begin{abstract}
ABSTRAK
Tindak kekerasan seksual setiap tahunnya mengalami peningkatan, baik daerah perkotaan maupun pedesaan, menunjukkan kondisi yang memprihatinkan. Berbagai strategi dilakukan dalam mengatasi kekerasan seksual pada korban agar bisa segera pulih. Strategi yang dipakai di antaranya mempraktikkan komunikasi terapeutik para relawan dan pendamping dalam melakukan rehabilitasi para para korban kekerasan seksual. Dengan menggunakan metode studi kasus, teknik pengumpulan data wawancara mendalam dan observasi, penelitian ini bertujuan untuk mencari tahu tentang strategi komunikasi terapeutik yang dilakukan tim relawan dalam pengobatan korban kekerasan seksual. Penelitian ini menghasilkan beberapa catatan penting mengenai strategi komunikasi terapeutik yang dilakukan tim relawan dan pendamping, yaitu melakukan komunikasi terapeutik secara bertahap kepada korban, dan setiap tahapannya memiliki tindakan-tindakan yang berbeda, namun tetap berkesinambungan antara tindakan yang satu dengan tindakan yang lainnya. Tahap pertama disebut sebagai tahap prapendampingan dengan melakukan penggalian informasi sebanyak-banyakya mengenai kondisi korban. Penggaliannya dilakukan kepada keluarga dan pihak-pihak yang bisa memberikan informasi akurat, dan setelah terkumpul datanya dilakukan klasifikasi korban. Tahap kedua, yaitu pendampingan, yaitu melakukan pendekatan kepada para korban agar korban terbuka dan percaya pada tim relawan. Tim relawan melakukan cara yang persuasif dan empati pada korban. Tahap ketiga, yaitu pasca pendampingan. Pada tahap ini tim terus melakukan komunikasi sebagai bentuk pemantauan terhadap perkembangan para korban kekerasan seksual. Agar tidak terjadi lagi kekerasan seksual, sebaiknya dilakukan keterbukaan dan keberanian dalam berkomunikasi di lingkungan keluarga maupun lingkungan tempat tinggal, sehingga ada keberanian dari anak yang akan atau menjadi korban kekerasan seksual untuk mengungkapkan apa yang dialaminya.
\end{abstract}

Kata-kata Kunci:Strategi; komunikasi terapeutik; pengobatan; kekerasan seksual; pendampingan

\section{Terapeutic communication strategies in treatment of victims of sexual violence}

\begin{abstract}
Acts of sexual violence have increased every year, both urban and rural areas, showing a worrisome condition. Various strategies are carried out in overcoming sexual violence against victims so that they can recover soon. The strategy used included practicing therapeutic communication of volunteers and assistants in rehabilitating victims of sexual violence. Using the case study method, in-depth interview and observation data collection techniques, this study aims to find out about the therapeutic communication strategies carried out by the volunteer team in the treatment of victims of sexual violence. This research produced several important notes about the therapeutic communication strategy carried out by volunteer and companion teams, namely conducting therapeutic communication in stages to the victims, and each stage had different actions, but still continued between one action with another. The first stage is called the pre-accompaniment stage by extracting as much information as possible about the victim's condition. The excavation is carried out to families and parties who can provide accurate information, and after the data is collected the classification of victims. The second stage, namely assistance, is approaching victims so victims are open and trusting in the volunteer team. The volunteer team did a persuasive and empathetic way to the victim. The third stage namely posts mentoring. At this stage, the team continued to communicate as a form of monitoring the development of victims of sexual violence. In order to prevent sexual violence from happening again, it is better to be open and courage in communicating in the family environment or in the neighborhood, so that there is courage from children who will or become victims of sexual violence to express what they are experiencing.
\end{abstract}

Keywords: Strategy; herapeutic communication; treatment; sexual violence; assistance

Korespondensi: Encep Dulwahab, M.I.Kom. Universitas Islam Negeri Sunan Gunung Djati Bandung 40614. Email: encep.dulwahab@uinsgd.co.id 


\section{PENDAHULUAN}

Berdasarkan catatan Report of SecretaryGeneral on Conflict-Related Sexual Violence pada 15 April 2017 periode Januari-Desember 2016, bahwa tindakan kriminal dalam bentuk kekerasan seksual begitu memprihatinkan. Jumlahnya setiap tahun terus mengalami peningkatan di beberapa negara. Misalnya kekerasan seksual terhadap kaum perempuan hampir merata di beberapa negara. Berdasarkan data dari The World's Women 2015 bahwa sekitar $40 \% 1$ dari 3 perempuan telah mengalami kekerasan seksual. Kemudian perempuan yang mengalami kekerasan seksual dari pasangannya hampir terjadi di setiap negara, seperti di negara-negara Amerika Utara $32 \%$, Eropa 46 $\%$, Afrika $64 \%$, Amerika Latin $38 \%$, dan Asia $67 \%$ (Department of Economic and Social Affairs, 2015).

Terdapat sekitar $19 \%$ wanita, dan $2 \%$ lakilaki mengalami pemerkosaan, dan sekitar $44 \%$ wanita dan $33 \%$ laki-laki mengalami tindakan kekerasan seksual lainnya (Breiding, 2014). Kemudian data dari National Intimate Partner and Sexual Violence Survey (NISVS) bahwa selama 2010 lebih dari 51,1 \% perempuan diperkosa oleh teman terdekat, dan 40,8\% oleh orang yang baru dikenal. Sementara menurut M.C. Black bahwa korban kekerasan seksual laki-laki lebih dari 52,4\% diperkosa oleh orang yang baru dikenal, dan 15,1\% diperkosa oleh orang yang tidak dikenalnya (Black et.al, 2011).

Tidak terkecuali di Indonesia, jumlah kekerasannya pun terus memperihatkan peningkatan. Pada laporan tahun 2017 dari Komisi Nasional Perempuan bahwa pada tahun 2016 telah terjadi kekerasan kepada kaum hawa dan anak-anak sekitar 259.150 kasus. Alan (2017) pernah melakuakn survei tentang kekerajuga menunjukkansan fisik dan seksual, hasilnya menunjukkan bahwa sekitar 33,4 \% atau 1 dari 3 perempuan usia 15-64 tahun telah merasakan kekerasan fisik dan seksual.

Tindakan keji dan amoral ini tidak hanya kepada perempuan, tetapi juga kepada anakanak yang mengerikannya lagi, pelakunya adalah orang-orang sekitarnya, baik oleh ayah kandung atau ayah tiri, kakek, paman, guru, atau teman bermain. Seperti yang terjadi di beberapa kota dan kabupaten di wilayah Provinsi Jawa Barat. Bisa dilihat pada tabel 1.

Para korban tersebut tidak bisa dibiarkan
Tabel 1 Jumlah Korban Kekerasan Seksual di Jawa Barat

\begin{tabular}{clc}
\hline No & Kota/Kabupaten & Jumlah Korban \\
\hline 1 & Kota Sukabumi & 116 orang \\
2 & $\begin{array}{l}\text { Kabupaten } \\
\text { Sumedang }\end{array}$ & 11 orang \\
3 & $\begin{array}{l}\text { Kabupaten } \\
\text { Cirebon }\end{array}$ & 6 orang \\
4 & Kabupaten Cianjur & 39 orang \\
5 & Kabupaten & 21 orang \\
& $\begin{array}{l}\text { Bandung } \\
6\end{array}$ & $\begin{array}{l}\text { Kabupaten } \\
\text { Sukabumi }\end{array}$ \\
7 & $\begin{array}{l}\text { Kabupaten } \\
\text { Tasikmalaya }\end{array}$ & Karang \\
8 & $\begin{array}{l}\text { Kabupaten } \\
\text { Bandung Barat }\end{array}$ & 28 orang \\
\hline
\end{tabular}

Sumber: P2TP2A Jawa Barat, 2014

begitu saja. Mereka harus diobati dan dipulihkan secara mental, dan cara pengobatannya ialah dengan menggunakan pendekatan komunikasi. Komunikasi yang biasa digunakan setiap orang dalam memenuhi kebutuhan sehari-hari, bisa dipakai dalam memulihkan semangat hidup dan mental para korban untuk bangkit dari dampak tindak kekerasan seksual yang diterimanya. Dan di antara komunikasi yang sering dipakai untuk penyembuhan dan pemulihan orang sakit, khususnya sakit psikologis, yaitu komunikasi terapeutik (M Damaiyanti, 2008). Tentu komunikasi terapeutik ini bisa langsung seketika menyembuhkan pasien atau korban kekerasan seksual, tetapi membutuhkan perencanaan, berbagai pertimbangan, dan dilaksanakan dengan penuh profesionalitas.

Sebagaimana disinggung tadi, bahwa tujuan dari komunikasi terapeutik adalah untuk menolong korban atau pasien yang menderita secara psikis yang dilakukan orang yang profesional, oleh karenanya harus menggunakan pendekatan perasaan atau emosi. Tidak hanya itu harus dibangun kepercayaan di antara perawat, dokter atau tim relawan dengan korban atau pasien ketika mereka berkomunikasi, jangan sepihak yang lebih aktif berkomunikasi, menghilangkan keraguan di antara para pelaku komunikasi, dan melakukan tindakan-tindakan 
efektif, mempererat hubungan dalam rangka membantu menyelesaikan masalah korban (Roos \& Kusnarto, 2015).

Ada strategi dan langkah-langkah efektif dalam komunikasi terapeutik, sebagaimana disebutkan dalam Textbook of Psychiatry bahwa ada beberapa pakar yang menjelaskan tahapan atau langkah komunikasi terapeutik sebagai strategi komunikasi terapeutik, di antaranya: Tahapan komunikasi terapeutik dari Hildegard E. Peplau yang memperkenalkan cara pengembangan hubungan pasien dan perawat, yang terdiri dari beberapa tahapan mulai dari orientasi kondisi pasien, identifikasi masalah pasien, menggali masalah pasien, dan resolusi sebagai upaya mencari solusi yang dihadapi pasien (Sotiri et al., 2012).

Pakar selanjutnya yaitu J. A. Devito, yang menjelaskan bahwa ada tiga dimensi yang senantiasa dilibatkan selama proses komunikasi, yaitu fisik, sosial, psikologi, dan ketiganya ketika berkomunikasi tidak bisa dipisahkan. Fisik berarti ketika berinteraksi dengan pasien harus ada kontak mata. Sosial berarti tidak bisa terpisahkan hubungan dengan orang lain yang ada di masyarakat. Psikologi memahami kondisi psikis pasien. Northouse dan Northouse menjelaskan bahwa strategi komunikasi terapeutik dengan cara sentuhan, sehingga pasien akan menerima sentuhan dalam cara yang positif. Sentuhan ini untuk situasi yang khusus (Sotiri et al., 2012). Dan sentuhan ini tidak hanya sebatas sentuhan secara fisik, tetapi juga sentuhan terhadap perasaan, atau dengan kata lain empati terhadap beban penderitaan korban.

Knapp dan Hall menyebutkan beberapa teknik komunikasi terapeutik, yaitu pengulangan pesan-pesan kepada pasien agar mudah dipahami, menyempurnakan langkahlangkah atau tindakan, pengaturan dalam berkomunikasi atau pendekatan agar tidak jenuh dan menakutkan pasien, dan penekanan agar menjadi perhatian pasien (Sotiri et al., 2012). Mengenai teknik pengulangan pesan dalam komunikasi terapeutik, Potter dan Perry mengingatkan bahwa ada aspek yang berbeda dari komunikasi verbal (Potter \& Perry, 1993). Pertama, komunikator harus memiliki perbendaharaan kata yang cukup sehingga pesan-pesan yang disampaikannya mudah dipahami pasien. Kedua, intonasi harus baik agar dapat menunjukkan beberapa penekanan perawat ketika berkomunikasi dengan pasien. Ketiga, pesan harus jelas dan ringkas namun dapat dengan tepat dan relevan menunjukkan saran atau solusi yang diberikan perawat kepada pasien. Hampir sama dengan yang dikatakan Knapp dan Hall, Arnold dan Boggs menyebutkan beberapa teknik komunikasi terapeutik, yaitu kedekatan antara perawat dengan pasien, variasi budaya ketika melakukan pendekatan dengan pasien, kinestetik termasuk bahasa tubuh dan ekspresi wajah agar pasien mengetahui kalau perawat betul-betul mengapresiasi dan merespon ketika berkomunikasi, dan penampilan fisik perawat yang membuat pasien nyaman atau menghormati (Sotiri et al., 2012).

Tahapan-tahapan atau strategi komunikasi terapeutik di atas bisa dipakai dalam berbagai konteks kehidupan atau fenomena kehidupan di masyarakat. Misalnya saja pengobatan atau rehabilitas pada para pecandu narkoba bisa menggunakan jenis komunikasi terapeutik ini, seperti yang diperlihatkan oleh Roos dan Kusnarto dalam penelitiannya kepada para pasien yang menjadi pecandu narkoba di Yayasan ORBIT. Hasil penelitiannya menunjukkan ada 5 hal yang harus diperhatikan ketika melakukan komunikasi terapeutik, yaitu menghormati pasien, memperlihatkan kesungguhan dalam mengobati pasien, berempati pada pasien, memberikan kepercayaan pada pasien, dan menjaga kerahasiaan pasien (Roos \& Kusnarto, 2015). Dalam penelitian ini memperlihatkan bahwa strategi komunikasi terapeutik yang dilakukan tenaga medis ialah dengan menggunakan cara mendengarkan, mengulang dan memberikan saran (Prasanti, 2017).

Betapa penting dan bermanfaatnya komunikasi terapeutik pada pasien sebagai cara pengobatan, termasuk dalam pengobatan anak yang fobia. Seperti yang dijelaskan Rachmaniar bahwa ada strategi khusus dalam komunikasi terapeutik pada anak yang fobia (Rachmaniar, 2015):

Metode yang digunakan orang tua untuk mengatasi anak fobia spesifik dapat dilihat dari teknik komunikasi terapeutik verbal yang dilakukan secara tidak rutin dan langsung, sehingga bisa menghasilkan noticeable experience models (media asli - sesungguhnya) dan playing experience models (media permainan). Sementara teknik komunikasi terapeutik nonverbal - menghasilkan vicarious experience models (media wakilan - videoclip 
dan buku cerita, rutin, tidak langsung), dan alasan orang tua menggunakan komunikasi terapeutik karena bisa fokus pada anak dengan mengedepankan rasa empati - mencari sesuatu yang disukai anak, mencari sesuatu yang dapat menarik perhatian anak, dan mengedepankan komunikasi antarpribadi orang tua terkait objek fobia anak.

Hal yang sama dikatakan Utami bahwa komunikasi terapeutik sangat penting dan berguna bagi para korban atau klien, karena komunikasi terapeutik bisa membantu korban atau klien dalam mengatasi masalah-masalah yang sedang dihadapinya (Ditha Prasanti, 2017). Komunikasi terapeutik bisa menggali masalah yang dihadapi pasien, dan membantu memulihkan kondisi psikis pasien.

Banyak penelitian tentang penggunaan komunikasi terapeutik dalam pemulihan pasien, namun masih kurang penelitian komunikasi terapeutik yang fokus kasusnya pada korban kekerasan seksual. Padahal seiring perkembangan zaman, problematika pelecehan sampai kekerasan seksual memiliki peluang yang meningkat. Oleh karena itu, tujuan dari penelitian ini adalah untuk menggali strategi komunikasi terapeutik pada korban kekerasan seksual di daerah pedesaan dengan latar belakang pendidikan, ekonomi, dan budaya yang relatif rendah.

\section{METODE PENELITIAN}

Penelitian ini menggunakan metode studi kasus, dan sebagaimana yang dijelaskan Yin bahwa metode studi kasus ada dua, yaitu metode studi kasus ke dalam single-case dan metode studi kasus multiple-case. Metode studi kasus Single-case digunakan dalam penelitian ketika kasus yang ditelitinya merupakan kasus yang ekstrim atau unik, memenuhi untuk menguji teori, memiliki kesempatan untuk mengobservasi dan menganalisis fenomena yang sebelumnya tidak diselidiki secara ilmiah. Sedangkan multiple-case memungkinkan dilakukannya perbandingan di antara beberapa kasus yang diteliti (Yin, 2009). Untuk metode yang digunakan dalam penelitian ini, adalah metode studi kasus satu kasus, yaitu kasus mengenai pelecehan sampai bentuk tindak kekerasan seksual.

Peneliti menggunakan teknik wawancara mendalam kepada para korban kekerasan seksual dan tim relawan sebagai key informant, dengan kriteria korban yang masih tinggal di lingkungan penelitian, dan korban yang mengalami trauma ringan sampai trauma berat. Pada penelitian ini, digunakan nama samaran untuk menjaga privacy para korban kekerasan seksual yang menjadi key informant. Selain wawancara, peneliti juga melakukan observasi ke lokasi penelitian untuk mengetahui bagaimana tim relawan melakukan pendekatan, melihat aktivitas para korban kekerasan seksual, dan melihat aktivitas korban kekerasan seksual di lingkungan tempat tinggalnya. Untuk pendalaman materi dan konsep, peneliti juga melakukan studi pustaka.

Data-data yang sudah terkumpul dilakukan analisis data dengan melalui beberapa tahapan. Pertama, klasifikasi data, yaitu data-data dari hasil wawancara sampai studi pustaka disesuaikan dengan tujuan dari penelitian ini. Kedua, interpretasi data, yaitu data-data yang sudah terkumpul dan terklasifikasi sesuai tujuan penelitian ditafsirkan dan dimaknai. Dan ketiga, penyajian data, langkah terakhir berupa penyampaian data yang telah dimaknai.

\section{HASIL DAN PEMBAHASAN}

Korban yang mendapatkan perlakuan kekerasan seksual di Kampung Ciseureuh Desa Cijambu Kecamatan Cipongkor Kabupaten Bandung Barat berjumlah 28. Dari 28 korban kekerasan seksual tersebut tidak sama mendapat perlakuan seksualnya dari pelaku kekerasan seksual. Ada yang masuk pada kategori korban kekerasan seksual yang ringan, sedang, dan berat. Ada yang hanya sekali mendapat kekerasan seksualnya, ada yang dua kali, bahkan ada juga yang mendapat beberapa kali kekerasan seksualnya.

Para korban kekerasan seksual tentu banyak yang mengalami trauma. Trauma pasca mengalami kekerasan seksual tersebut beragam, ada yang trauma namun masih bisa berkomunikasi, ada juga yang menutup diri dari kehidupan dan diam diri di dalam kamar tidak mau bertemu dengan orang lain, bahkan ada juga yang trauma sampai tidak bisa bicara (berkomunikasi) sama sekali dengan orang lain.

Strategi komunikasi terapeutik yang dilakukan tim pendamping P2TP2A terhadap para korban kekerasan seksual yang terjadi di 


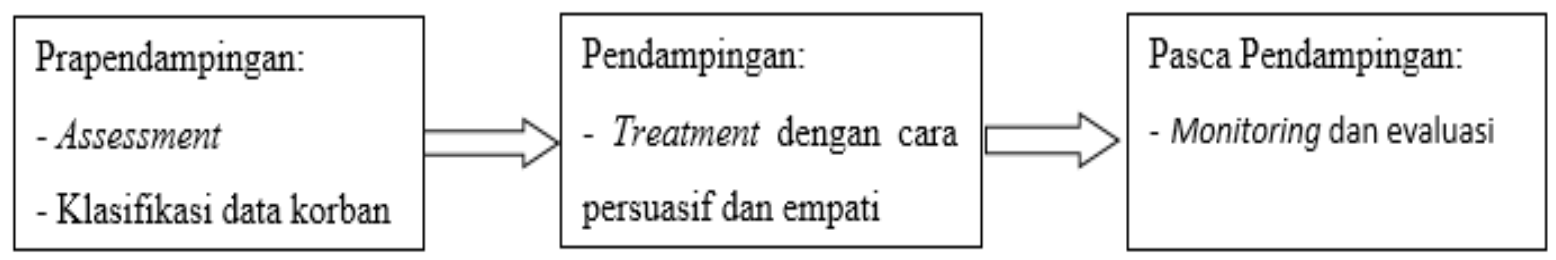

Sumber: Hasil penelitian, 2019

\section{Gambar 1 Tahapan Strategi Komunikasi Terapeutik Tim Pendamping terhadap Korban Kekerasan Seksual di Cipongkor Kabupaten Bandung Barat}

Cipongkor Kabupaten Bandung Barat cukup sederhana dan praktis, namun komunikasi terapeutik dilakukan dalam waktu yang relatif panjang, melalui beberapa tahapan, dan memiliki prosedur yang cukup kompleks. Lebih mudahnya bisa dilihat pada gambar 1 .

Tim pendamping dan relawan tidak sembarang dan langsung berkomunikasi dengan para korban. Tim pendamping melakukan pemetaan terlebih dahulu, pemetaan situasi dan kondisi, geografis dan demografis, klasifikasi korban dan memilih korban sehingga bisa diidentifikasi perlakuan dan komunikasi dengan para korban.

Strategi komunikasi yang pakai tim relawan dengan para korban pun tidak disamaratakan, tetapi dibedakan antara korban yang satu dengan korban yang lainnya. Untuk korban yang tidak terlalu trauma bisa langsung dilakukan komunikasi secara tatap muka. Berbeda dengan korban yang sangat traumatik atau depresi berat karena beban yang didapatkan ketika menjadi korban kekerasan seksual, proses komunikasinya tidak langsung, tetapi ada beberapa tahapan komunikasi terapeutiknya. Ada prosedur yang harus ditempuh dan tidak langsung berkomunikasi.

Strategi komunikasi terapeutik yang dilakukan tim P2TP2A dengan para korban kekerasan seksual berlangsung sepihak, atau dalam komunikasi disebut dengan satu arah (one way communication), artinya tim pendamping yang proaktif menghampiri, dan terus aktif mengajak korban kekerasan seksual untuk berkomunikasi. Tentu saja tidak mudah untuk berkomunikasi dengan korban, oleh karena itu dibutuhkan usaha ekstra dan kerja intensif dari tim pendamping. Karena harus berhasil melakukan komunikasi secara tatap muka. Namun berkat kegigihan dan keuletan tim, tim pendamping akhirnya mampu diterima oleh para korban dan keluarga korban. Akhirnya mereka bisa dekat dengan korban dan keluarga korban, meskipun di awal-awal sempat ditolak oleh warga akan kehadirannya membantu para korban.

Setelah berusaha beberapa kali, tim dapat diterima dengan baik oleh masyarakat dan keluarga korban. Kegiatan pendampingan dan pengobatan pun dilakukan tim relawan kepada korban. Dalam pendampingannya, tim membutuhkan waktu yang lama. Kurang lebih selama 3 bulan tim relawan melakukan tugasnya, sehingga wajar kalau mereka bisa dekat dan akrab dengan keluarga atau korban kekerasan. Saking dekatnya tim pendamping dengan korban, sampai-sampai para korban tidak mau berpisah dengan tim, ketika tim mau mengakhirikegiatan pendampingan di Kampung Ciseureuh Desa Cijambu Kabupaten Bandung Barat, karena terasa manfaat keberadaannya.

Jauh sebelum benar-benar diterima dan melekat di hati para korban dan keluarga korban, terlebih dahulu tim melakukan persiapan komunikasi. Ada beberapa langkah dan tahapan yang dilakukan tim dalam menyusun proses komunikasi. Di antaranya melakukan assessment dengan mengundang pihak-pihak luar untuk terlibat dalam kegiatan ini. Di antaranya para pejabat dan tokoh masyarakat. Untuk pejabatnya mulai dari MUI tingkat Kecamatan sampai MUI tingkat Kabupaten Bandung Barat, Dinas Pendidikan Kabupaten Bandung Barat, KUA sampai Kementerian Keagamaan Kabupaten Bandung Barat, dan Dinas Sosial Kabupaten Bandung Barat.

Tahapan ini merupakan tahapan strategi dalam pengumpulan informasi tentang kondisi 
objektif korban, situasi dan kondisi lingkungan korban, dan lain sebagainya. Kemudian tim P2TP2A tidak langsung berkomunikasi dengan para korban dan keluarga korban, tetapi berupaya membekali diri dengan berbagai bahan, informasi, data dan pengetahuan-pengetahuan yang detil tentang kondisi korban kekerasan, situasi dan suasana lingkungan tempat tinggal korban. Tim melakukan penggalian informasi, sehingga benar-benar mengetahui kondisi terakhir setiap korban. Langkah awal ini semacam identifikasi korban. Berangkat dari sinilah tim memiliki data sekaligus bahan yang bisa dipetakan situasi dan kondisi setiap korban. Termasuk dapat memikirkan program-program, cara-cara pendekatan yang bisa dipakai untuk berkomunikasi dengan korban kekerasan seksual.

Selain berkomunikasi dengan pihak-pihak terkait yang oleh tim dianggap representatif dan kompeten dalam melakukan pendampingan terhadap korban kekerasan seksual, tim juga melakukan beberapa langkah sebagai bagian dari persiapan dalam melakukan proses komunikasi dengan korban dan keluarga korban. Di antaranya analisis wilayah, penelusuran wilayah, mencari tempat tinggal untuk tim, perancangan program, rekrutmen tim, dan kontrak kerja relawan, penyediaan perangkat program, membentuk tim pendamping korban yang terdiri dari tenaga ahli psikologi sesuai dengan kasus korban.

Tim melakukan analisis wilayah mulai dari geografi, demografi, lingkungan, habit masyarakat, budaya dan berbagai hal yang berkaitan dengan situasi dan kondisi masyarakat setempat. Kemudian mencari tempat tinggal sementara sebagai pusat kegiatan, di samping mengunjungi ke rumah-rumah korban. Tempat ini yang mudah diakses, strategis dekat dengan rumah korban, dan memiliki beberapa fasilitas yang memenuhi standar sebuah rumah untuk basecamp pendampingan terhadap korban. Tim terdiri dari orang-orang yang bisa fokus dan stand by di lokasi dengan kompetensi yang sesuai dengan standar dalam penanganan kasus kekerasan seksual. Setelah ada tempat yang dianggap representatif, dan tim mulai terbentuk, barulah dibuat program-program pendampingan dan lain sebagainya. Disinilah tim mulai melaksanakan kegiatannya.

Ada beberapa manfaat dan tujuan adanya penggalian data, kemudian klasifikasi korban yang masuk kategori depresi berat dan stress ringan. Dengan harapan tepat dan sesuai dalam melakukan terapinya. Termasuk ketika melakukan kapan terapi kelompok dan kapan terapi individunya. Ada perlakuan yang berbeda antara korban satu dengan korban yang lain. Komunikasi yang dilakukan juga berbeda antara korban yang berat dengan korban yang dianggap ringan. Perbedaan tersebut juga termasuk penyesuaian materi-materi pelatihan dalam rangka membangkitkan spirit dan motivasi para korban. Contoh perbedaan tersebut terjadi saat melakukan terapi yang dilakukan individu dan kelompok, terapi kelompok berbeda dengan individu. Di dalam terapi tersebut juga terdapat pelatihan dan pelaksanaan, selain itu juga diberikan materi pendampingan materi public speaking kepada para pendamping dan korban agar mereka berani bicara dan lantang bicara.

Ada beberapa tahapan dalam komunikasi dengan para korban, salah satu yang terpenting adalah tahapan intervensi psikologis. Secara teori, untuk intervensi ini ada panduan dan rujukan pelaksanaannya. Namun tidak dapat dimungkiri bahwa dalam pelaksanannya terdapat hal-hal yang tidak sesuai dengan pedoman. Tidak semua panduan dilaksanakan, hanya beberapa saja tergantung korban, lingkungan, dan situasi kondisi.

Setelah melakukan intervensi, tahapan selanjutnya adalah tim melakukan komunikasi dengan korban menggunakan cara role play dan psikodrama. Para korban diajak bermain gamegame yang ringan, dan membuat para korban semangat, tertarik, antusias, dan mau mengikuti terus kegiatan yang dilakukan tim pendamping. Bukan hanya itu, tim pendamping juga menyisipkan humor-humor agar komunikasi dengan para korban dapat berlangsung secara nyaman dan santai.

Lokasi pendampingan komunikasi yang dilakukan tim P2TP2A dimulai di rumah korban. Mereka bergerak aktif datang ke rumah-rumah karena pada awalnya korban tidak mau keluar rumah. Mereka merasa diri kotor dan menutup diri dari orang lain. Akan tetapi, dengan pendekatan yang hangat dan perlahan, melalui komunikasi antara tim dengan para korban atau keluarga korban, mereka akhirnya sedikit demi sedikit mulai mau berinteraksi dengan pihak luar. Meskipun komunikasi sudah dilakukan di rumah atau tempat tinggalnya sendiri. Pihak korban tetap tidak bisa seutuhnya terbuka 
dalam komunikasi. Mereka hanya berinteraksi secara terbatas. Kondisi ini menjadi hambatan bagi tim dalam melakukan assessment dan penggalian data-data yang dibutuhkan dalam membuat planning kegiatan pendampingan berikutnya terhadap korban tersebut. Untuk menghadapi ketertutupan para korban, tim melakukan pendekatan komunikasi dengan dongeng-dongeng atau cerita-cerita yang menarik perhatian korban.

Dongeng atau cerita-cerita tersebut cukup efektif, ini terbukti dari meningkatnya kemauan mereka untuk berkomunikasi. Para korban tersebut mau bercerita kepada tim P2TP2A peihal pengalaman-pengalaman buruk mereka menjadi korban kejahatan seksual. Di samping dengan kekuatan dongeng dan cerita, kelebihihan tim P2TP2A yang membuat mereka dapat diterima oleh para korban adalah bahwa anggota tim mayoritas merupakan perempuan. Secara psikologis, korban lebih terbuka kepada perempuan dibanding laki-laki. Hasilnya, ketika sudah terbuka maka tim dengan mudah dan leluasa melakukan role play dan FGD dalam mengeksplore kisah-kisah pengalaman pahit para korban.

Hasil dari penggalian data dan informasi yang dilakukan tim P2TP2A menunjukkan bahwa wawasan dan pengetahuan para korban mengenai seks ternyata masih minim. Mereka belum memahami anatomi tubuh dan organorgan tubuh mana yang tidak boleh disentuh oleh orang asing atau orang lain, termasuk lakilaki. Para korban benar-benar masih polos dan tidak tahu menahu perihal seksualitas. Bisa jadi keluguan para korban itu karena para korban masih remaja, bahkan ada korban yang masih tergolong anak-anak. Mereka rata-rata 11-15 tahun. Banyaknya anak-anak yang menjadi korban karena mereka masih sangat mudah diintimidasi. Selain itu, mereka mengalami ketakutan karena diancam oleh pelaku untuk menuruti kehendak dan memenuhi hawa nafsu bejatnya.

Korban yang masih anak-anak dan latar belakang budaya dan pendidikan keluarga dan korban yang masih rendah, tidak serta merta memudahkan dalam berkomunikasi antara tim dengan para korban dan keluarga korban. Berbagai cara dan teknik komunikasi pun dilakukan dalam memuluskan cara berinteraksi, sehingga para korban ini bersedia berkomunikasi sampai menceritakan kejadian dan mau mengungkapkan hal yang sesungguhnya.

Tidak semua komunikasi terapeutik terhadap korban memerlukan waktu yang lama. Terdapat juga pelaksanaan komunikasi terapeutik dengan korban yang relatif cepat dan mudah. Cepat atau lamanya ini bergantung pada kondisi psikis korban dan tingkat kekerasan seksual yang dialaminya. Semakin parah kekerasan seksual yang dialami maka semakin lama waktu yang dibutuhkan.

Setelah tim melakukan pendampingan tahap selanjutnya adalah evaluasi. Apabila hasil evaluasi menunjukkan bahwa sudah layak untuk mengakhiri kegiatan pendampingan terhadap korban kekerasan seksual, maka selanjutnya korban diserahkan ke keluarga dan masyarakat. Kegiatan tentu saja tidak berhenti sampai di sini, tim akan terus memantau dan berkomunikasi dengan para korban untuk memantau perkembangan psikologis dan aktivitasnya.

Komunikasi terapeutik yang dilakukan oleh P2TP2A ini memang merupakan sebuah proses yang panjang. Diperlukan strategi yang mumpuni sehingga korban dari awalnya tertutup menjadi mau terbuka. Dari keterbukaan ini kemudian tumbuh rasa percaya dirinya dan memiliki kemampuan atau skill yang bisa menambah nilai kepercayaan dirinya. Untuk melakukan komunikasi terapeutik ini, diperlukan tim relawan memiliki semangat yang tinggi, tekun dan sabar dalam menghadapi korban, mau mendengarkan, memperlihatkan sikap yang empati dan supportif pada korban, teliti dan terus bertanya pada korban agar korban mau cerita atau curhat pada tim relawan. Tim relawan juga harus dapat memberikan apresiasi dan penghargaan pada korban ketika para korban ini berhasil meraih prestasi.

Dalam melakukan komunikasi terapeutik, tim relawan awal mulanya dengan cara satu arah dan pesannya senantiasa tertunda. Tentu kondisi ini berbeda dengan strategi komunikasi terapeutik yang idealnya harus berlangsung dalam kondisi dua arah, dan pesannya tidak tertunda. Mayoritas para korban mengalami depresi dan tidak siap bertemu dengan para tim relawan, akhirnya proses komunikasi menjadi terhambat. Kondisi ini pun sama dari hasil penelitian Sable et.al (2006) bahwa para korban pemerkosaan akan merasa malu, rasa bersalah, tertutup dan tidak ingin keluarga dan temantemannya tahu apa yang terjadi pada dirinya. 
Kesuksesan komunikasi mereka juga karena tim relawan selali hadir langsung ke lokasi di mana korban berada. Kunjungan ke rumah-rumah korban dilakukan berkali-kali agar mereka bisa dekat, akrab, dan berdialog dengan korban. Seperti yang disarankan (Damaiyanti, 2008) bahwa dalam konteks terapeutik, seorang pendamping harus benarbenar bisa terlihat, baik secara fisik maupun psikologis ketika berkomunikasi dengan korban kekerasan seksual, dengan tujuan agar bisa berkomunikasi secara tatap muka.

Langkah-langkah yang dilakukan tim pendamping atau relawan terhadap korban kekerasan seksual serupa dengan langkahlangkah yang pernah dilakukan konselor ketika melakukan komunikasi terapeutik pada kliennya, yang secara umum ada tiga tahapan besar yang dilakukan konselor, yaitu: pertama, tahap pembinaan hubungan baik dengan klien, kedua, tahap pengumpulan informasi tentang klien, dan ketiga, tahap penyelesaian masalah klien (Dewi, 2015). Adapun untuk teknik komunikasinya, konselor dalam konseling $r$ menggunakan 10 teknik komunikasi, yaitu:

Komunikasi nonverbal, mendengarkan, mengajukan pertanyaan, menggunakan respons sederhana, berempati, menghindari kata-kata menghakimi atau menilai, menerima apa yang klien pikirkan, mengenali dan memuji, memberikan informasi yang relevan, dan terakhir memberikan saran (Dewi, 2015).

Di antara sepuluh teknik komunikasi terapeutik yang dilakukan konselor pun sama dilakukan oleh tim relawan yang menjadi pendamping para korban kekerasan seksual. Para tim melihat dan bertemu langsung dengan korban dan melihat bagaimana respon atau gesture yang diberikan para korban ketika berinteraksi dengannya. Kemudian ketika ada korban yang berani dan mau bicara, dengan seksama tim mendengarkan dengan penuh perhatian. Ketika ada hal-hal yang tidak jelas atau membutuhkan informasi lebih mendalam, tim mencoba mengajukan pertanyaan yang disesuaikan dengan kemampuan anak korban kekerasan seksual. Setelah tim mendapatkan data yang lebih, tim tidak mencoba menghakimi dengan berbagai perkataan yang menyinggung, tetapi menggunakan bahasa yang empatik dan memberikan sarang yang menyemangatkan korban.

Tim relawan membangun hubungan baik dengan tidak langsung berkomunikasi dengan pesan yang seragam. mereka melakukan pendekatan secara bertahap, dan tindakan dibedakan antara satu korban dengan korban lainnya. Seperti hasil penelitian Sherko yang menyatakan bahwa ketika melakukan komunikasi terapeutik kita harus bisa membangun hubungan yang baik, mengidentifikasi kecemasan dan kebutuhankebutuhan pasien, mempelajari perilaku dan pesan-pesan yang diberikan pasien (Sherko etal., 2013). Ketika tim relawan memahami kondisi korban, mulai dari kecemasan, kebutuhan pasien, dan pesan-pesan baik secara verbal atau nonverbal, maka tim akan mudah dan cepat membantu para korban kekerasan seksual untuk bangkit. Zivanovic juga mengatakan bahwa komunikasi terapeutik merupakan proses perawat watua dokter yang secara sadar bisa membantu korban dengan memahami korban, baik melalui komunikasi verbal maupun nonverbal, kemudian mendorong korban untuk mengungkapkan perasaan dan gagasannya, sehingga terealisasi hubungan penerimaan dan saling menguntungkan (Zivanovic, 2017).

Tim relawan yang mengutamakan hubungan antarpribadi dengan para pasien korban kekerasan seksual juga sesuai dengan apa yang menjadi temuan dalam sebuah penelitian bahwa strategi komunikasi terapeutik mengutamakan efektivitas hubungan antarpribadi dengan tahapan mendengarkan, mengulang dan memberikan saran (Prasanti, 2017). Tidak ada unsur paksaan, atau ancaman dalam melakukan tindakan pendampingannya. Hal yang sama juga dikatakan O'gara dan Fairhust ada lima strategi dalam komunikasi terapeutik, yaitu bertanya, mendengarkan dan memperhatikan, berempati, membangun kepedulian dan perhatian pada pasien, dan menyimpulkan (O'gara \& Fairhurs, 2004). Begitu pun dengan hasil penelitian Abdolrahimi bahwa komunikasi terapeutik membangun hubungan interpersonal, proses berbagi informasi, penting menguasai kemampuan mengobati, peduli dan fokus pada pasien (Abdolrahimi et al., 2017).

Berhasil tidaknya praktik komunikasi terapatik yang dilakukan tim relawan kepada para korban kekerasan seksual, hal itu bisa terlihat dari tingkat kepuasan korban sendiri. Kondisi korban berbeda jauh ketika sebelum dilakukan treatment dengan korban setelah 
adanya pendampingan. Korban yang awalnya takut dan tidak mau bicara dengan orang lain, dengan adanya pendampingan ini, mulai mendapatkan harapan dan kembali beraktivitas seperti biasa. Tim relawan sudah memiliki kemampuan dan terlatih dalam melakukan pendekatan dan komunikasi dengan para korban, karena mereka telah seringkali mengikuti pelatihan-pelatihan seperti yang disarankan Rahmawati, bahwa komunikasi yang efektif dari penyedia kesehatan diasosiasikan dengan kepuasan korban. Komunikasi penyedia kesehatan sebaiknya terlibat dalam pelatihan meningkatkan keahlian komunikasi untuk memuaskan para korban (Rahmawati et al., 2017).

Lambat atau lamanya tim relawan diterima oleh warga Kampung Ciseureuh dan para korban kekerasan seksual, bukan hanya karena faktor trauma, tetapi juga dipengaruhi oleh beberapa faktor psikologis dan psikis. Potter dan Perry menyebutkan sembilan unsur yang bisa mempengaruhi praktik komunikasi terapeutik akan berlangsung lama (Potter \& Perry, 1993), di antaranya: usia, persepsi, latar belakang sosial budaya, emosi, jenis kelamin, pengetahuan, peran dan hubungan, lingkungan dan jarak. Faktor-faktor ini pun yang dialami tim pendamping atau relawan ketika melakukan pendampingan kepada para korban kekerasan seksual. Berikut penjelasan setiap faktor yang mempengaruhinya.

Perkembangan para korban secara psikis dan fisik telah terganggu, oleh karenanya seringkali menghambat ketika berkomunikasi dengan orang lain. Seorang pendamping dan tim harus bisa memahami perkembangan para korban, baik dari sisi bahasa yang digunakan para korban, maupun cara berpikir para korban kekerasan. Dengan memahami perkembangan fisik dan psikis para korban, tim relawan akan tahu cara berkomunikasi termasuk pesan-pesan yang pas. Kendalanya adalah, tidak sedikit tim relawan yang belum memahami perkembangan fisik dan psikis.

Selain faktor-faktor tersebut, perlu juga diperhatikan faktor persepsi. Persepsi yang dimaksudkan adalah pandangan seorang korban kekerasan terhadap sesuatu atau peristiwa yang dialaminya. Persepsi para korban kekerasan ini dibentuk oleh pengetahuan, wawasan, lingkungan dan pengalaman-pengalaman sebelumnya. Pengalaman dan masa lalu korban yang negatif membuat persepsinya juga negatif. Komunikasi terapeutik juga dipengaruhi olehkemampuan berbahasa dan gayakomunikasi tim pendamping. Bahasa atau gaya komunikasi ini pun dipengaruhi budaya. Tim relawan lahir dan besar pada budaya yang berbeda, dan budaya yang pertama kali dikenalnya juga telah membentuk karakter dan mengajarkannya dalam bertindak dan berkomunikasi. Khusus mengenai latar belakang sosial budaya ini, Stewart L. Tubss dan Sylvia Moss mengatakan bahwa perubahan adat istiadat juga menuntut banyak perubahan dalam cara penggunaan bahasa (Moss \& Tubbs, 1996).

Faktor selanjutnya ialah emosi, yang merupakan perasaan subyektif seseorang atas kejadian yang dialaminya. Hal yang sama juga dirasakan para korban kekerasan, kebencian, kesal, kesedihannya, dan dendam pada pelaku atau menyesali pengalaman pahit dalam hiduipnya, akan mempengaruhi para korban kekerasan ketia berinteraksi dengan tim relawan. Tim relawan perlu mempelajari emosi korban kekerasan dan keluarganya, sehingga mereka akan mampu memberikan pelayanan dan melaksanakan tugasnya secara efektif. Selain itu, tim relawan juga perlu mengkontrol perasaannya sehingga ketika melaksanakan tugasnya dalam memberikan pelayanan atau pendampingan kepada korban kekerasan, tidak terpengaruh oleh emosi bawah sadarnya.

Kemudian faktor jenis kelamin yang bisa mempengaruhi praktik komunikasi terapeutik. Karena setiap orang, terlebih laki-laki dan perempuan, pada prinsipnya dibekali sejak lahir dengan modal untuk berkomunikasi dengan gaya tersendiri yang berbeda. Perempuan maupun lelaki memiliki cara berkomunikasi yang berbeda. Sejak usia tiga tahun, kalangan perempuan ketika berinteraksi dengan temantemannya yang seusia dengan tujuan untuk mencari kejelasan, mengurangi perbedaan dan mencari kesamaan dengan temannya, dan membangun kedekatan atau keakraban dengan temannya. Berbeda dengan anak laki-laki yang ketika berkomunikasi dengan teman-temannya dengan tujuan untuk mendapatkan kemandirian. Dalam mengekspresikan perasaan, pikiran, dan emosinya antara laki-laki dengan perempuan pun berbeda. Pada umumnya laki-laki akan lebih berani atau ekspresif dibanding perempuan yang lebih malu-malu dan tertutup. Tubbs dan Moss menambahkan, bahwa berdasarkan pada 
percobaan yang dilakukan Piaget kalau anak yang berusia kurang dari tujuh atau delapan tahun, bahasa memiliki dua fungsi yang berlainan, sehingga cara berbicara juga dua macam pula, yaitu pembicaraan egosentrik artinya pembicaraan yang fokus pada diri sendiri atau untuk diri sendiri, dan pembicaraan sosialisasi atau pembicaraan yang bertujuan berinteraksi dengan orang lain untuk sosialisasi diri (Moss \& Tubbs, 1996).

Tingkat pengetahuan pun mempengaruhi komunikasi yang dilakukan antara tim relawan dan korban kekerasan. Oleh karena itu, petugas atau tim relawan harus mengetahui tingkat pengetahuan dan pendidikan setiap korban atau kliennya, sehingga tim relawan dapat berkomunikasi secara efektif, dan bisa meraih maksimal dalam membantu para korban untuk bangkit dari keterpurukannya setelah mengalami tindak kekerasan seksual.

Pola komunikasi terapeutik sebenarnya tidak bisa persis sama antarsetiap orang, kalau dilihat pada peran dan hubungan antara korban dengan tim relawan. Ketika hubungan tim relawannya semakin dekat dengan korban kekerasan seksual, maka korban akan semakin terbuka untuk mengungkapkan isi hatinya. Lingkungan tempat dilakukannya komunikasi terapeutik juga ikut menentukan tingkat efektivitas dalam berkomunikasi antara korban dan tim relawan. Misalnya ketika berkomunikasi antara tim relawan dengan korban, tempatnya banyak gangguan suara kendaraan atau pabrik, dilakukan di tempat umum yang orang bisa melihat atau mendengar masalah pribadinya, atau di tempat-tempat formal seperti kantor desan, kepolisian, yang membuatnya tegang dan tidak nyaman atau menjadi lebih takuat. Untuk itulah tim relawan harus menyadari dan menggunakan tempat yang membuatnya santai sehingga bisa mengungkapkan isi hatinya, baik para korban maupun keluarga korban.

Faktor lain yang juga berpengaruh adalah jarak. Jarak yang dimaksudkan adalah ketika tim relawan berkomunikasi dengan korban kekerasan. Jarak yang terlalu jauh bisa membuat pesan yang diterima susah dipahami, karena namanya juga orang sakit secara fisik dan psikis, maka akan susah berbicara seperti orang sehat pada umumnya. Namun sebaliknya ketika jarak terlalu dekat, akan sulit juga berkomunikasi karena bisa jadi korban malu atau tidak nyaman. Tim relawan bisa mengecek dan mengujinya, bagaimana reaksi atau respon korban ketika diajak bicara teralu jauh, apakah nyaman atau tidak. Kalau sekiranya sudah nyaman berarti korban tersebut tidak bermasalah ketika bicara dengan jarak yang terlalu dekat. Sebaliknya kalau ada korban yang kelihatannya tidak nyaman dengan jarak yang terlalu dekat, sebaiknya segera agak menjauh jaraknya dari korban.

Mengenai jarak komunikasi antara tim relawan dengan para korban kekerasan seksual, Hall membagi beberapa jenis jarak dalam berkomunikasi, di antaranya: Pertama, jarak intim yang jaraknya kurang lebih 1 meter. Dalam jarak yang intim ini, ketika bicara akan tampak jelas, dan hal ini kadangkadang tampak berlebihan untuk orang yang baru pertama kali bertemu. Berbeda untuk orang yang sudah sangat dekat, mereka tidak sungkan-sungkan untuk bicara dengan jarak yang bisa kurang dari 1 meter; Kedua, jarak pribadi. Jarak pribadi ini ukurannya kurang lebih dari satu setengah meter sampai dua meter. Jarak pribadi ini biasanya topik yang dibahas masalah pribadi. Dan orang yang melakukan komunikasi dengan jarak seperti ini biasanya orang yang sudah dekat secara pribadi; Ketiga, jarak sosial, berkisar dari dua sampai 3 meter jarak antara orang yang berkomunikasi. Karena secara psikologis orang yang belum akrab dia akan menjaga jarak dan sedikit menghindar. Jarak ini cocok untuk diskusi dan percakapan dalam pertemuan sosial; Keempat, jarak publik, merupakan jarak komunikasi dengan banyak orang yang jaraknya bisa lebih dari 3 meter, dan hanya muncul dalam suasana formal. Pembicara publik yang berpengalaman memperbanyak gerakan tubuh, sikap, ucapan, dan mengeraskan suara, sedangkan kecepatan berbicara dikurangi (Moss \& Tubbs, 1996).

Melihat strategi dan tahapan dalam melakukan komunikasi terapeutik yang dilakukan tim relawan kepada korban kekerasan seksual di Cipongkor Kabupaten Bandung, hal ini juga sesuai dengan strategi komunikasi terapeutik yang dipaparkan Stuart dan Sundeen, di antaranya tim relawan mendengarkan apa yang dikatakan korban dengan khusyu (Stuart \& Sundeen, 1998). Ketika mendengarkan dengan khusyu, tim relawan sedang memahami penderitaan dan penyakit yang diderita korban kekerasan, dengan cara mendengarkan apa yang disampaikannya. Tim relawan memposisikan 
korban orang yang penting, dan setiap ucapannya di dengar dan diingat.

Menurut Floyd bahwa ada tiga hal yang memerlukan mendengarkan, yaitu dalam meraih keberhasilan dalam menjalankan tugas, dalam melakukan perlindungan diri, dan penegasan-penegasan lainnya sebagai bentuk tindakan mendengarkan seseorang merupakan penegasan yang kuat. Dalam praktik komunikasi terapeutik, mendengarkan yang baik dilakukan para tim relawan ialah mendengarkan dengan empati. Karena mendengarkan dengan empati antara seorang korban dengan ahli psikoterapi merupakan hal penting dalam penggalian informasi dari korban (Moss \& Tubbs, 1996).

Tim relawan bersedia meluangkan waktu, tenaga dan pikirannya untuk mendengarkan keluh kesah yang dirasakan para korban. Ketika menerima keluh kesah dari para korban, bukan berarti mereka menyetujui dan menganggap benar apa yang dirasakannya itu sesuai dengan anggapan korban. Dengan mendengarkan para korban bercerita, tim sudah membantu meringankan beban para korban, dan para korban akan lebih menaruh kepercayaan kepada mereka.

Namun jika ada kesempatan, tim relawan bertanya kepada para korban, dengan tujuan untuk mendapatkan informasi yang lebih dalam dan detil dari yang dikatakan oleh para korban. Oleh karena itu, pertanyaan yang diajukan tim relawan sebaiknya sesuai dengan topik yang sedang dibicarakan. Selain itu, juga tim relawan ketika bertanya, harus memakai kata-kata yang sesuai dengan kemampuan korban. Tim relawan mengulang apa yang diucapkan korban dengan menggunakan kata-kata tim relawan. Ini dilakukan dengan tujuan untuk melakukan konfirmasi oleh tim relawan kepada korban, atau memastikan bahwa informasi yang didapatkan tim relawan adalah benar atau sesuai dengan yang dirasakan korban. Melalui pengulangan kembali kata-kata korban, berarti tim relawan telah memberikan umpan balik pada korban, sekaligus menunjukkan bahwa tim relawan mengerti pesan yang diberikan korban, sehingga langkah selanjutnya yang akan diambil tim relawan tidak salah. Karena bisa jadi maksud dan tujuan korban belum tentu dipahami benar oleh para tim dan relawan. Dalam istilah (Moss \& Tubbs, 1996) bahwa setiap orang berpotensi menafsirkan sesuatu sesuai dengan makna pribadi dan makna bersama.
Ada saatnya tim relawan diam untuk memberikan kebebasan korban dalam memutuskan sendiri. Karena ketika diam diri itu sama dengan membiarkan korban untuk mengatur pola pikir dan pandangannya. Jangan sampai tim relawan juga ikut bicara sehingga memotong ucapan korban, tentu saja kalau ini terjadi korban akan merasa tersinggung, bahkan akan menghentikan pembicaraannya.

Memberikan penghargaan. Penghargaan layak diberikan kepada korban yang telah berhasil melaksanakan saran atau petunjuk dari tim relawan. Atau juga petugas medis bisa memberikan penghargaan ketika setiap hari ada progress dari korban yang lebih baik dari hari sebelumnya. Hal ini dilakukan untuk memulihkan dan memberikan motivasi pada pasien. Penghargaan juga layak diberikan ketika ada lomba-lomba yang memacu korban untuk berkompetisi.

Memberikan kesempatan kepada korban untuk mengungkapkan pandangannya. Biarkan korban berpendapat sehingga tim relawan hanya bisa melihat posisi dan pandangan korban. Dengan seperti ini, korban akan merasa bebas untuk menguraikan pandangannya kepada tim relawan. Selain itu, dengan cara membebaskan atau meminta korban berpandangan atau berargumentasi, itu sama dengan kita memberikan keberanian korban dalam mengungkapkan isi hatinya, selanjutnya akan memunculkan keberanian dalam dirinya.

Tim juga melakukan refleksi. Refleksi ini memberikan kesempatan kepada korban untuk merenungi apa yang terjadi dan dialami oleh dirinya. Dengan cara ini bisa membantu korban dalam introspeksi sehingga ke depannya bisa memperbaiki kekurangan-kekurangan diri yang ditemukan setelah refleksi. Ini merupakan tahap akhir, setelah korban dinilai telah memiliki kepercayaan diri yang sebelumnya hilang atau tidak memiliki sama sekali. Langkah ini sama dengan mengajarkan para korban untuk memikirkanmasa depannya harus diciptakan dan diraihnya. Merenungkan hal-hal negatif yang pernah dialami, untuk kemudian merenungkan hal-hal positif yang akan dilakukan sebagai cara menghilangkan masa-masa sulit.

Di samping beberapa strategi komunikasi terapeutik, juga perlu adanya peningkatan kualitas komunikasi terapeutik dari para tim relawan atau pendamping. Dengan tim relawan dan pendamping yang berkualitas sehingga 
memiliki kredibilitas di depan para korban kekerasan seksual. Pentingnya kredibilitas petugas atau tenaga ahli ini juga diperkuat hasil penelitian bahwa kredibilitas petugas berpengaruh kepada pasien tingkat kepercayaan pasien untuk memeriksakan dirinya (Kosasih et al., 2017; Niftah \& Rahmat, 2017)

\section{SIMPULAN}

\begin{tabular}{ccr} 
Strategi & \multicolumn{2}{c}{ komunikasi terapeutik } \\
terhadap para & korban kekerasan reksual \\
di Cipongkor & Kabupaten Bandung Barat
\end{tabular}
berjenjang dan memiliki tahapan-tahapan yang panjang. Setidaknya ada tiga tahapan, yaitu prapendampingan, pendampingan dan pascapendampingan. Di dalam tahapan prapendampingan, yaitu tim melakukan beberapa kegiatan, mulai dari mengumpulkan berbagai informasi dan menggali data-data tentang korban dari keluarga korban, dan berbagai pihak yang dianggap bisa memberikan data akurat sehingga bisa mendapatkan kondisi korban yang akurat, selanjutnya pada tahap pra pendampingan ini tim melakukan klasifikasi korban agar memudahkan dalam melakukan treatment. Tahap kedua tim relawan melakukan tindakan yang disesuaikan kondisi setiap korban yang sudah diklasifikasikan pada tahap pertama. Setelah itu tim mulai mendekati korban dengan sering bertemu, mulai mengajak korban berkomunikasi, tim memperlihatkan kepedulian, menjelaskan posisi dan tujuannya keberadaan tim ke pihak keluarga dan korban, dan memberikan dukungan moral dan spirit kepada setiap korban. Terakhir, pasca pendampingan dengan melakukan komunikasi intensif sesuai dengan situasi dan kondisi tiaptiap korban kekerasan seksual. Pada tahap ini juga seringkali dilakukan pemantauan dari jarak jauh untuk melihat perkembangan para korban.

Berdasarkan penelitian ini bahwa perlu kiranya membangun budaya komunikasi yang terbuka, baik di lingkungan keluarga maupun masyarakat sekitar, sehingga harus bisa memunculkan keterbukaan di antara anggota keluarga dan masyarakat. Selain itu, perlu juga ada pembekalan strategi-strategi dalam komunikasi terapeutik untuk tim relawan atau pendamping korban kekerasan seksual.

\section{DAFTAR PUSTAKA}

Abdolrahimi, M., Ghiyasvandian, S., Zakerimoghadam, M., \& Ebadi, A. (2017). Therapeutic communication in nursing students: A Walker \& Avant concept analysis. Electronic Physician Journal, 9(8), 4968-4977.

Alan, F. (2017). Darurat kekerasan seksual. Pikiran Rakyat.

Black, M., Basile, K., Breiding, M., Smith, S., Walters, M., Merrick, M., Chen, J., \& Stevens, M. (2011). National intimate partner and sexual violence survey (nisvs): 2010 summary report. CDC.

Breiding, M. (2014). Prevalence and characteristics of sexual violence, stalking and intimate partner violence victimzationnational intimate partner and sextual violence survey 2011. MMWR Surveill Summ Journal, 63(8), 1-18.

Damaiyanti, M. (2008). Komunikasi terapeutik dalam praktik keperawatan. Bandung: Refika Aditama.

Department of Economic and Social Affairs. (2015). The World's Women: Trends and Statistics. New York: United Nations.

Dewi, R. (2015). Komunikasi terapeutik konselor laktasi terhadap klien relaktasi. Jurnal Kajian Komunikasi, 3(2), 192-211.

Kosasih, E., Setianti, Y., \& Wahyudin, U. (2017). Pengaruh kredibilitas petugas terhadap sikap kepatuhan pasien tuberkulosis pada pemeriksaan dahak. Jurnal Kajian Komunikasi, 5(1).

Moss, S., \& Tubbs, S. L. (1996). Human communication: prinsip-prinsip dasar. Bandung: Remaja Rosdakarya.

Niftah, Y., \& Rahmat, A. (2017). Pengaruh kredibilitas konselor terhadap sikap remaja mengenai hiv/aids di sukabumi. Jurnal Kajian Komunikasi, 5(2), 159-167.

O'gara, P. E., \& Fairhurs, W. (2004). herapeutic communication part 2: strategies that can enhance the quality of the emergency care consultation. Accident and Emergency Nursing., 12(4), 201-207.

Potter, \& Perry. (1993). Buku ajar fundamental keperawatan: konsep, proses, dan praktik. Vol. 1. EGC.

Prasanti, D. (2017). Komunikasi terapeutik tenaga medis tentang obat tradisional bagi masyarakat. Mediator, 10(1), 53-64. 
Rachmaniar, N. (2015). Komunikasi terapeutik orang tua dengan anak fobia spesifik. Jurnal Kajian Komunikasi, 3(2), 93-111.

Rahmawati, D., Verity, F., Mulyana, D., Roselina, E., \& Anindhita, W. (2017). A therapeutic communication study of families with children suffering from cancer. Mimbar, 33(2).

Roos, D., \& Kusnarto. (2015). Komunikasi terapeutik dalam penyembuhan pecandu narkoba (studi deskriptif komunikasi terapeutik dalam penyembuhan pasien pecandu narkoba di yayasan panti rehabilitasi orbit surabaya). Jurnal Ilmu
Komunikasi.

Sherko, E., Sotiri, E., \& Lika, E. (2013). Therapeutic communication. Jurnal JaHR, 4(1).

Sotiri, F., Elezi, S., Tomorri, E., \& Dobi, F. (2012). Textbook of psychiatry. Tirane.

Stuart, G. W., \& Sundeen, J. S. (1998). Keperawatan jiwa (Terjemahan). EGC.

Yin, R. K. (2009). Studi kasus desain \& metode. Bandung: Raja Grafindo Persada.

Zivanovic, D. (2017). Therapeutic communication in health care. SciFed Nursing \& Healthcare Journal, 1(17). 